\title{
Reinterpreting the Historicity of the Nordic Model
}

\section{Pauli Kettunen'}

Professor, Department of Political and Economic Studies, University of Helsinki, Finland

\begin{abstract}
In conventional images of the so-called Nordic model, the strong state is opposed to markets or civil society and co-operation is opposed to conflict. These opposites appear problematic if one takes seriously the Nordic market- and interest-centered language used for the practices of social regulation, including the stubborn use of "labor market parties" instead of the EU concept "social partners". Applying an approach sensitive to the historical and political aspects of language and concepts, the paper argues that a particular notion of social citizenship developed in the Nordic countries, in which interests rather than rights were put into the center. Such a notion of social citizenship was associated with two intertwined ideas, important in the development of the Nordic pattern of social reform: the idea of symmetry between workers and employers and the idea of a virtuous circle between divergent interests. With these ideas democracy and citizenship were combined with paid work and conflicting interests. This combination has been questioned by the projects for competitive national (and European) communities, responding to globalized and financialized capitalism. The vigorous comparisons of "models", and the popularity of the concept of "the Nordic model", can be seen as an aspect of this current transformation.
\end{abstract}

\section{KEY WORDS}

Competitiveness / compromise / consensus / European integration / globalization / industrial relations / labor market parties / Nordic model / social citizenship / virtuous circle / welfare state

\section{Introduction}

- he warm vocabulary of "social partners" and "social dialogue" was adopted in the language of the European Union in the 1980s. This same vocabulary is also included in the constitutional Lisbon Treaty. In the Nordic countries, however, "social partnership" has not become a popular term. The official translations of the Lisbon Treaty and other EU documents into Danish, Finnish and Swedish, the languages of the three Nordic EU members, use "labor market parties" (arbejdmarkedsparter, arbetsmarknadsparterna, työmarkkinaosapuolet) instead of "social partners". Both expressions share a notion of symmetry, yet they differ in two ways. In the Nordic concept, "labor market" appears instead of "social", and "parties" instead of "partners". One may interpret that the Nordic vocabulary is focused on markets and conflicting interests, whereas the EU language indicates a notion of community and different functions harmoniously complementing each other.

Although social practices are not to be reduced to language and concepts, it is, nevertheless, important to recognize the crucial role of language and concepts in

\footnotetext{
${ }^{1}$ Department of Political and Economic Studies, P.O. Box 54, FIN-00014 University of Helsinki, Finland. E-mail: pauli.kettunen@helsinki.fi
} 
defining the targets and agents of knowledge and politics. It may not be just a paradoxical coincidence that the symmetric communitarian language of social partnership gained popularity in Europe at a time of increasing asymmetries between labor and capital in globalized capitalism. Arguably, this language not only reflects an old legacy of social Catholicism but is also associated with current projects for reshaping nation-states and the European Union as competitive communities. This vocabulary of harmony stems from traditions of social thought which are divergent from Nordic thinking and it also indicates a current challenge for the so-called Nordic model. In order to understand this challenge, however, we should go beyond the conventional images of the Nordic model in which the strong state is opposed to markets or civil society and co-operation is opposed to conflict. We should take seriously the Nordic market- and interest-oriented vocabulary.

This article is not an analysis of new empirical findings, but a historical reinterpretation of facts mostly well-known to those interested in the past and present of the Nordic welfare states and industrial relations. The methodological guideline for my reinterpretation demands sensitivity to the historicity of concepts and the ability to take conceptualizations as an inherent part of politics and policies.

I begin by critically discussing two influential accounts of a powerful role of the state in Norden - the thesis of "decommodification" by Gøsta Esping-Andersen and the thesis of "statist individualism" by Lars Trägårdh - and I argue, at a general hypothetical level, that a particular notion of social citizenship developed in the Nordic countries, in which interests rather than rights were put into the center. I then examine the emergence of two intertwined modes of thought and action through which such a notion of social citizenship became a part of the Nordic pattern of social change and reform: the idea of symmetry between workers and employers and the idea of a virtuous circle between divergent interests. With these ideas democracy and citizenship were combined with paid work and conflicting interests. It is this combination that has been questioned by the projects for competitive national (and European) communities, responding to globalized and financialized capitalism. In the last part of the paper, I focus on the ways this change was defined as a new challenge in the Nordic countries, especially in trade unions and in the large national working life development programs of the 1990s. The defense of the Nordic model was oriented to prove that the Nordic model in general, and the specific national traditions in particular, provide a good means for successfully responding to the new imperatives of competitiveness. I argue that the discursive change has been associated with an institutional one in which old welfare-state institutions have been modified to serve new competition-state functions.

The vigorous comparisons of "models", and the popularity of the concept of "the Nordic model", can be seen as an aspect of this current transformation. At the end of this paper, I discuss the ambiguous usage of "the Nordic model" from this point of view. I only hesitantly use this concept as my own tool. The main reason is not that Denmark, Finland, Iceland, Norway and Sweden are different and may be found to represent one model with five exceptions. Rather, the differences of the Nordic countries, and their similarities with other countries in Europe and also, for instance, in the Australasian region (Lloyd 2011), in no way preclude the significance of the Nordic context in the making of national welfare-states and industrial relations systems. Yet, the concept of "model" not only tends to provide a too static and tensionless image of the dynamics and controversies of this process; used as an analytical tool it may also hinder the 
researcher from paying attention to the political role this concept plays in the constant comparisons between different institutional settings that are an integral aspect of globalized competition (Kettunen 2006; Kettunen \& Petersen 2011). Thus, the concept of "(Nordic) model" is here included in the target of research rather than in the box of analytical instruments.

\section{Wage work and social citizenship}

Accounts of the Nordic welfare state tend to repeat the lesson of the Danish sociologist Gøsta Esping-Andersen (1985; 1990) on how the Nordic "politics against markets" resulted in a high degree of "decommodification". This concept refers to policies that liberate people from their dependencies on markets, notably from uncertainties associated with the character of labor as a commodity. The emphasis on the labor market in the Nordic vocabulary of social regulation, however, seems to be at odds with this characterization of the Nordic model. Practices of social regulation are conceptualized in a way that does not deny that labor is a commodity and does not even aim to abolish such a state of affairs. The Nordic countries seem to show little respect to a main constitutional principle of the International Labor Organization, ILO, declaring that "labor is not a commodity" ${ }^{1}$ However, the Nordic labor-market language does not indicate a confidence in unregulated markets or market-based spontaneous harmony. Instead, it is a language of regulation. "Labor market parties" is a concept for regulation by compromises between voluntary organizations representing divergent interests and by governmental policies influenced by these organizations.

When one takes the language used for the practices of social regulation seriously, then the conceptual opposites employed for describing the Nordic model appear problematic. Such opposites include not only the state versus the market but also the state versus civil society. The latter distinction emerged in the 1980s and was applied as a conceptual tool for criticizing the welfare state. Notably in Sweden, the critics observed that the concept of "civil society" confronting the state was missing and took this as an evidence of a patronizing state. In this debate, the Swedish historian Lars Trägårdh (1997) did not approve this conclusion, as such, and developed a thesis on "statist individualism". He argued that in the Nordic countries, in particular Sweden, the strong state came to be oriented to provide resources for individuals and to thus promote their autonomy. In Sweden and other Nordic countries, the notion of a (civil) society confronting the state did not develop because, on the basis of the egalitarian tradition of independent peasants, the liberation of the individual was not targeted against excessive state power but against the privileges and patriarchal powers of those between the state and the people. Another factor preventing the conceptual separation of state and society was the absence of conflicts between the state and church and between confessional communities. The Reformation in the sixteenth and seventeenth centuries had been a process of the making of the centralized state, inseparably intertwined with the Lutheran church and its lessons of conformity, while Lutheran Christianity at the same time pointed out an immediate individual relationship to God.

All this resulted, according to Trägårdh, in a Social Democratic welfare state characterized by "statist individualism". Social solidarity was realized through high taxes, public systems of social security and public services for health, care and education that 
helped to liberate people from the personal relations of subordination, especially those in the family. Social security was based on "the individual-state social contract" (Trägårdh 1997, p. 270). As a part of this contract, women were made doubly dependent on the welfare state, both on public sector jobs and on the services that facilitated combining motherhood and employment outside the home.

The theses on "decommodification" and "statist individualism" are opposite to any simple view that identifies the strong state with the patronizing of people. However, both of these theses bypass something important. The policies they refer to have not just protected individuals from the imperatives and arbitrariness of markets nor simply liberated them from subordinating social relationships in family and working life. "Politics against markets" actually promoted the development of labor market rationalities, not least by reinforcing workers' position as parties in individual and collective contracts with employers. Removing paternalistic ties of social subordination did not mean that the individuals and the state would have simply remained as the parties to the "social contract" as the thesis on "statist individualism" seems to argue. Rather, the individual as a party in social relationships has been a major concern in Nordic social and labor market policies. The normalcy of waged and salaried work was reinforced at the same time as it was adjusted with a universalistic principle of social citizenship.

In the post-World War II decades, the goal of full employment, with varying normative notions of work, was a way in which the normalcy of wage work and the principle of social citizenship emerged in parallel and intertwined. The simultaneous reinforcement of these two principles also became characteristic of social policies. In the field of social security, the normalcy of wage work and social citizenship were reinforced by the social insurance policies contributing to the development and functioning of labor markets. Especially in pension policies, transportable social benefits, by diminishing workers' dependence on single employers, strengthened their positions as sellers of their labor power. This was also promoted by the work-performance and income-related definitions of these benefits. True, work-performance and income-related benefits did not in any self-evident way fit to the universalistic idea of social citizenship (Edling 2006; Petersen \& Åmark 2006). However, through the power of strong trade unions, a secured continuity of income actually became interpreted as a right associated with citizenship, or as an aspect of social citizenship.

The normalcy of wage work and the notion of social citizenship were also reinforced by the construction of extensive public services. These services, defining and meeting the needs of health, care and education, bore the character of universal social rights at the same time as they created the preconditions for the generalizing of wage work as the norm. A transformation of the gender division of labor was crucial here, associated with redefined relationships between the family and society. As a result, a particular complexity developed between the welfare state, labor market regime and gender system, one crucial aspect being the strong gender-segregation of Nordic labor markets (Borchorst \& Siim 2008, pp. 207-224).

However, still another way of combining wage work and social citizenship can be recognized in Nordic countries. This might be characterized as a Utopian vision of equality within the relationships between workers and employers. In terms of my argument here, this vision of an interest-oriented social citizenship deserves particular attention. 


\title{
The empowerment of the sellers of labor power
}

The Dutch historian and history theorist Frank Ankersmit has criticized the American philosophers John Rawls and Richard Rorty for their search for an overlapping consensus. According to Ankersmit, they actually support the current juridical de-politicization of politics on the basis of the concept of rights. Instead, Ankersmit prefers to focus on interests rather than rights:

\begin{abstract}
Interests are, so to speak, rights in statu nascendi. Hence, much, if not all, that is from a political point of view new, unexpected, unforeseen, and unforeseeable in the development of a society will initially present itself in terms of interests and emphatically not in terms of rights and of the law case. [...] The conflict of interests gives us access to the nature of social and political reality and without it we are blind, politically speaking. The vocabulary of rights does not give us this access to social reality: it only exemplifies or expresses a certain conception of social reality without testing it in the way that typically happens when interests conflict (Ankersmit 2002, p. 205).
\end{abstract}

I will argue that recognizing and establishing interests has been crucial in Nordic ideas of social equalization and democratization through public and collective regulation. Here, as in general, "regulation" should be conceived as an integral factor in the conceptual and practical construction of its own targets (Jessop 1995). It is worth noting that interests are not, any more than rights, completely pre-given phenomena simply waiting for regulation. In the Nordic countries, notably in issues of work and the labor market, the regulation establishing rights and duties has been very much aimed to level social relations, so that these relations (especially those between workers and employers) could appear as parity-based encounters of particular divergent interests. These relationships would be, at the same time, processes of producing and reproducing the parties to these relationships. Thus, not only have interests been rights in statu nascendi, but also, conversely, rights have been interests in statu nascendi.

In his Great Transformation, Karl Polanyi concluded that the making of labor into a commodity was a necessary precondition of modern capitalism, yet it was a "fictitious commodity" since labor, and the production, selling and consumption of labor, were inseparable from the life of the wage workers themselves (Polanyi 2001 [1944], pp. 71-80). Polanyi preceded Esping-Andersen in arguing that social policies and trade unions are forces for the removal of human labor "from the orbit of the market" (ibid. 186). They were, for him, forces of the historical counter-movement against markets for rescuing the society. However, one can question whether the social policies and trade unions, notably in the Nordic countries, were actually oriented towards abolishing the character of labor as a commodity. Arguably, they were, instead, oriented towards abolishing the constraints and coercions stemming from the fictitious character of this commodity. Social and labor market policies, while creating non-market supportive institutions for preserving labor power when it is not traded in the labor market (cf. Offe 1984, p. 263), were liberating people's life courses from the necessities of selling labor power under any conditions and, thus, making labor more like a real commodity.

The concept of social citizenship needs further attention here. The British sociologist T. H. Marshall (1950) famously distinguished between three stages and aspects of citizenship, each associated with the rights the state guaranteed to individuals: civil 
rights, political rights and social rights. In Marshallian theory, a source of inspiration for Esping-Andersen, the focus is on the evolution and dimensions of the relationship between the state and the individual. In this regard, the perspective of social equality was associated with citizenship by means of individual social rights. No doubt, it is possible to analyze the Nordic developments of social security as the extension of this kind of social citizenship. However, the Nordic countries can also be found as a good case for recognizing the limits of such an understanding of how social equality and citizenship could be connected. In the Nordic countries, the connection between social equality and citizenship - the notion of social citizenship - developed through policies and collective actions, in which people were defined, and defined themselves, as parties of asymmetrical social relationships. Through these policies and collective actions they were empowered to articulate their interests within the framework of national society.

\section{Symmetry between labor market parties}

The idea of symmetry between labor market parties was, as such, far from being exclusively Nordic. "The ideology of parity" (Bruun 1979) was adopted as a crucial point of departure for the development of European labor law in the 19th and 20th centuries. The social liberals as well as the Marxists of the late 19th century shared the idea that the labor market is a particular kind of market and labor was a particular commodity. Social liberals concluded that the worker was the weaker party in the individual worker-employer relationship and consequently needed protection. At the collective level, however, parity would be realized through organization and collective agreements. In the 20th century, reformist trade unions widely adopted this mode of thought.

In the Marxian tradition of critical theory, the symmetrical appearance of labor market relationships is seen as an ideological disguise hiding the basic asymmetry of capital and labor. On the individual level, the relationship between the worker and the capitalist appears as a free market relationship, yet it is essentially a relationship of subordination and exploitation. At the collective level, as well, symmetry is a mere formal appearance that conceals the fundamentally different compositions of the two labor market parties. One of the most influential contributions in this critique of ideology is the analysis of "two logics of collective action" by Claus Offe and Helmut Wiesenthal (1980). They focus on the basic differences beyond the symmetrical outlook of trade unions and employer organizations concerning the actors they represent as well as their modes of creating and articulating collective interests.

However, in the Nordic industrial relations, which were shaped by influential trade unions associated with reformist Socialist movements, the symmetry of labor market parties came to mean something more than just a juridical form of regulating labor market conflicts or an ideological disguise of the basic asymmetry of capital and labor. The symmetry of collective labor market agreements became a criterion for an immanent critique. In this mode of critique society is criticized in the name of society itself, that is, by means of the normative standards that appear as the standards of society itself (Lohmann 1986). Since the 1930s and especially after World War II, the widening of the field of issues regulated through collective negotiations and agreements was conceived as a process of democratization. 
As early as in the 1930s, Denmark, Sweden and Norway were at the top in the international statistics of unionization. In Finland, the degree of unionization was much lower. At the beginning of the 20th century, a strong labor movement had developed in Finland, one of Europe's most rural countries and an autonomous Grand Duchy of the Russian Emperor. The political party organization within the Finnish labor movement at the time was considerably larger and, in social and geographic terms, wider than trade unions. Still, a very rapid rise of unionization did occur after the February Revolution of 1917. However, after the class-based Civil War of 1918, Finnish employers, especially in manufacturing industries, were able, until World War II, to adhere to the policy of refusing collective agreements with trade unions.

In Denmark, Sweden and Norway, the principle of collective agreements had achieved a recognized status and practical significance much before the 1930s. The socalled September Agreement of 1899 between the Danish peak organizations of workers and employers provided a model combining collective agreements with the employer's direction rights. Denmark as the forerunner and Finland as the latecomer also appears in the fact that Denmark, in the long-run, has been the most consequent and Finland the least consequent regarding the "Nordic" principle according to which collective agreements are the primary means of regulating individual employer-worker relations, and legislation the secondary means (Bruun 1990). However, in solving collective conflicts, legislation has been most used in Denmark and Norway, and least used in Sweden (Due, Madsen \& Strøby Jensen 1994; Elvander 2002; Stokke 2002).

In the 1930s, Scandinavian trade unions and employer organizations, urged on by experiences of widespread and harsh industrial conflicts, were ready to further specify the rules of the game and to consolidate the system of negotiations and agreements. This was manifested in the Norwegian hovedavtal (basic agreement) in 1935 and the Swedish Saltsjöbaden Agreement in 1938 between the peak organizations of trade unions and employer associations. In Finland the corresponding national-level basic agreements between the organized workers and employers were achieved in 1944 and 1946. The logics of these national agreements included that labor market parties reciprocally recognized the particular - and not the universal - and therefore legitimate nature of their interests. They committed themselves to taking into account through their mutual compromises the universal interest that was assigned to "society" and included objectives such as the prevention of damaging conflicts, the promotion of industrial efficiency, and the increase of purchasing power. ${ }^{2}$

Three principles came to be combined in Nordic working-life institutions: the regulation of labor market conflicts through parity-based collective agreements; the direction rights of employers, associated with different arrangements of employee participation; and the joint acceptance of rationalization in production and work processes (Kettunen 1998). This combination can be seen to correspond to three different rationalities mediating between what in the Habermasian terminology could be called workers' life-world and the systemic conditions of their living. Two rationalities are inherent in living by wage-work: that of the seller of labor power and that of the subject of labor process (Kern \& Schumann 1984). The third significant rationality here is that of citizenship.

Obviously, it has been difficult to adjust the rationality of an equal citizenship into the context of wage-work relations and hierarchical work organizations. One can also argue that the system of collective bargaining, as it follows the logic of the selling and buying of labor power, including trade union strategies for limiting the competition 
between individual workers, tends to reduce qualitative issues of working life into issues concerning the price of labor power and the quantity of labor exploited. However, the widening of the symmetrical party relations became crucial for the Nordic model of working-life reform. It was a vision in which the compromises of conflicting labor market interests would include the promotion of both democracy and the co-operation between actors fulfilling different functions in a company or in the society.

Trade unions became oriented to extend the field of parity-based relations, that is, the range of issues to be included in collective agreements. This strengthened their role within industrial relations, but still more fundamental aspect was that business companies and somewhat later even the state and municipalities, in their role as employers, were defined and organized as a 'party' representing (no more than) particular interests, and they had to recognize this not only in the setting of wages but also in many other issues of working life and management. The collective and public regulation of labor relations would empower the weaker party (workers) to take care of their interests and constrain the stronger party (employers) from presenting their interests as universal. This idea appeared at the "macro" level of the national economy and society, but also at the "micro" level of the business economy and enterprise. One can find a more or less explicit distinction between "enterprise" and "employer" in which the general interest of the enterprise was not simply identified with the action of management but rather conceived as an outcome of the agreements and negotiations between the employer and the workers, both of whom were simply representing their respective interests (Kettunen \& Turunen 1994, pp. 73-74; Flodgren 1990, p. 124).

In the 1930s, collective agreements were included in the concept of democracy, especially, by the Nordic Social Democratic parties and trade union movements. The strong trade unions were supposed to extend democracy in two senses, both as a popular movement and as one of the two "labor market parties" making parity-based agreements. In this way, "industrial democracy" in the Nordic countries was strongly associated with the widening and deepening of the system of collective agreements and the associated work-place level system of shop stewards, rather than referring to separate parallel institutions of personnel participation such as the German works councils, Betriebsräte (Knudsen 1995).

With their considerable power to set the agenda on working life issues, trade unions began to draw management issues into the sphere of collective agreements. In the Nordic discourse on working life reform, especially in the Swedish and Norwegian debates in the 1960s and 1970s, we can recognize a politically effective Utopian idea according to which the collective-level parity between the labor market parties had to be extended and woven into individual employer-worker relationships (Winner 1995; Claussen 2000). It was a vision of an interest-oriented social citizenship within wage-work relationships, different from Marshall's concept of social citizenship as an extension of citizenship through more extensive individual rights.

\section{Divergent interests and virtuous circles}

The interest-oriented social citizenship, based on the empowerment of the seller of labor power, was developed in the framework of a particular notion of national society. International dependencies provided the preconditions for strong notions of 
national economy and national society. Europe's Northern peripheries integrated in the expanding capitalism in nationally varying ways, yet, in general, the Nordic countries developed into small relatively open economies that were, each country in its specific way, highly dependent on exports and exposed to the cycles and crises of the world economy (Senghaas 1985; Katzenstein 1985). In connection with the Great Depression of the 1930s, class compromises brought new ingredients into the ways of conceiving society and economy. Reflecting class structures and conclusions from the economic crisis and the rise of Fascism in Europe, the Nordic class compromises of the 1930s included political coalitions of "workers and farmers", or Social Democrats and Agrarian Parties, and the consolidation of national systems of collective labor market negotiations and agreements (only the former applied to Finland before the Second World War).

In conclusions drawn from the Great Depression, the notion of national economy began to be based on new ideas of cumulative economic success. Virtuous circles would connect the interests of worker-consumers and farmer-producers as well as of workers and employers. Confidence in the positive-sum-games was institutionalized in class compromises, which initiated the period of Social Democracy in the Scandinavian countries, especially in Sweden. The practical significance of the new employment and economic policies before World War II has been debated. On the level of political discourse, however, the new Scandinavian ideas of a virtuous circle indicated important changes in the 1930s.

The idea of virtuous circles should not be reduced to the vulgarized Keynesian description of growing production through growing consumption. As early as in the 1930s there was considerable productivistic supply-side interest in the political orientation of the Scandinavian Social Democrats (Kulawik 2002; Andersson 2006). The promotion of social equality was held to be the means of releasing human productive capacities and, thus, the means of promoting economic effectiveness, which, in turn, was seen as a fundamental precondition for achieving social equality.

Any compromises reached between the conflicting interests remained a question of power. The mutual recognition that the interests of different groups indeed were divergent was a central part of the Nordic class compromises. However, new forms of systemic integration also appeared. The labor movement adopted the view that economic competitiveness, and thus the rationalization of production, was necessary in order to create resources for social welfare and equality. At the same time, bourgeois groups and employers admitted that the collective organization of labor and the widening of workers' social rights could bring economically positive outcomes, not least with respect to industrial peace. Somewhat paradoxically, the needs and interests of capital, or employers, were provided with a new moral and political legitimacy, and the needs and interests of the working class achieved a new national economic legitimacy.

The virtuous circle included something more than just positive-sum compromises between conflicting economic interests. It was also a virtuous circle between equality, efficiency and solidarity, which, in a sense, can be seen as being based on three different ideological strains of Nordic modernization processes: the idealized heritage of the free peasant, the spirit of capitalism and the utopia of socialism. In terms of political objectives, and of future expectations, the virtuous circle came to connect social equalization, economic growth and widening democracy. Different ways of interpreting these objectives and expectations appeared, yet in the post-World War II period they came to play a hegemonic role in the sense that political conflicts tended to be struggles on the right 
way to represent and promote these objectives and expectations and to conceive the interconnectedness between them.

The trust in a virtuous circle between economic growth, widening democracy and increased equality was not, as such, a Nordic specificity in the post-war decades. During World War II, it had become a more or less explicit part of the so-called post-war planning in Western countries. At the international level, it was manifested, for example, in the Philadelphia Declaration of the ILO in 1944 that came to form a part of the constitution of the organization. Among the main principles of the Declaration were the participation of workers' and employers' representatives in social policies, collective bargaining, full employment and the linkage between social equality, elimination of poverty and economic growth. The post-war development in Scandinavia, especially in Sweden, was perceived not only by some Nordic citizens but also by many others outside the Nordic region as uniquely consistent steps along such a universally applicable road to progress (Kettunen 2009). No doubt, in the Cold War world, more than one candidate for the universally applicable road existed. The notion of "the third way" or "the middle way", as it was associated with Sweden and sometimes with the whole Norden, included a particular claim of universality, expressed, for example, by maintaining that "freedom and welfare" was the principle of Nordic social political co-operation (Nelson 1953; Salvesen 1956).

\section{The Nordic model of democratic wage-work society}

The terms "Nordic society", "Nordic democracy", "Nordic welfare state" and "Nordic model" all refer to separate clusters of national institutions. There are significant differences between Denmark, Finland, Iceland, Norway and Sweden and important similarities with societies outside the Nordic region, in particular with the other small European countries to which terms like "democratic corporatism" (Katzenstein 1985) can be applied. However, this does not preclude that the many-layered ideological, practical and institutional intra-Nordic intercourses made a context in which national identities and institutions were shaped and a Nordic element was built in the divergent national identities and institutions (Kettunen 2006; Petersen 2006).

Through Nordic co-operation in the production of social knowledge, norms and arguments, the notion of a model of a national society was reinforced. In Finland, the concept of "Nordic society" came to represent a normative standard and a code for the future inherent in Finnish society. The normative standard and the future code were often interpreted in terms of everything that had "already" been achieved in Sweden. This notion of Finland the Nordic latecomer served as an argument for social reform demands, although there was a conservative alternative that was also influential. According to the latter, the Finns at their lower stage of economic development should wait and see how the reform in question would work in Sweden (Kettunen 2006).

Tough competition on the world market between the Nordic countries has served as an important backdrop for intra-Nordic comparisons and contacts. For example, the competition between the Finnish and Swedish wood-processing industries was a contributory factor in making the Swedish trade union movement willing to help the Finnish trade unions to strengthen their influence in determining wage levels in Finnish industry. The Finnish trade union movement was much weaker than the Swedish one 
before the Second World War and indeed right up to the 1960s, and it lacked, due to the strong Communist movement, the Social Democratic internal cohesion that was such a pronounced characteristic of the Swedish movement.

The Nordic region has functioned as a frame of reference within which national institutions have been shaped. On the other hand, transnational elements were also built into the construction of the Nordic framework. The freedom to cross intra-Nordic borders without passports was established in 1952, a hot year in the Cold War and the year of the founding of the Nordic Council. Two years later, an agreement on a common Nordic labor market was established. Ambitious political objectives were formulated in the agreement, including the concerted maintenance of full employment (Salvesen 1955, pp. 339-340).

A common labor market helped reveal asymmetrical relationships between the Nordic countries. Four hundred thousand Finns emigrated to Sweden in the post-war decades, most eagerly in the late 1960s, which had impacts in both countries. Although this migration was a consequence of a rapid and profound change of Finnish social and regional structures and a response to the demand for labor in the Swedish economy, the exit option of the Finnish labor force also increased the power resources of Finnish trade unions (Bergholm 2012, ch. VII).

In the 1970s, it was easier than before - or later - to recognize common Nordic characteristics in national institutions, policies and future prospects. These included many work-related features:

- a strong dominance of wage work/salaried work as a social form of work.

- active policies for full employment: everyone should have the right to fulfill his or her moral duty to work.

- a high degree of female employment outside the home: the central role of paid work in the views on gender equality.

- the two-hold dependence of women on the welfare state: social political preconditions for employment outside the home; jobs in the labor market with a strong gender-segregation.

- the principle of universalism (rights and benefits associated with citizenship) in the organizing of welfare and education.

- a high rate of unionization among the employees (men as well as women, blue-collar as well as white-collar workers, public as well as private sector employees).

- a high rate of organization among employers (and other interest groups), as well.

- a national hierarchical system of collective bargaining, including the strong presence of trade unions at the workplace level.

- the priority of collective agreements to direct statutory norms in the regulation of working life.

- tripartite cooperation between trade unions, employers' organizations and the government on issues of economic and social policies (corporatism).

- a close connection between the formation of the welfare state and industrial relations.

These characteristics had emerged and were intertwined as a pattern for constructing a modern nation-state society, in which institutions were based on waged and salaried work and supported its expansion and normalcy, including the paid work of women outside 
the home. In the Nordic countries, waged and salaried work became the predominant social form of work even more over whelmingly than elsewhere in the so-called developed countries. By European and OECD comparisons, the Nordic countries belong to those with the lowest share of entrepreneurs in the economically active population (van Stel 2008, pp. 79-82). One may use the concept of "the Nordic model" for these characteristics, yet one should not understand it simply as existing institutions but, rather, as a pattern of change and reform. It consisted of principles and practices that defined ways of dealing with social change and of making reforms, that is, of setting the political agenda.

The combination of the normalcy of wage work and the principle of social citizenship was reinforced in the post-World War II Norden 1) through the policies of full employment, 2) through the construction of social security systems and public services that came to manifest citizenship-based universalism at the same time as they followed and supported labor-market rationalities, and 3) through the regulation of industrial relations by agreements between highly organized labor and capital, oriented towards a symmetry between the parties of employment relationships. These policies and processes were shaped within the framework of a widely shared confidence in virtuous circles that could be achieved through interest compromises in a national society.

\section{The questioning of symmetries and virtuous circles}

Since the 1980s, crucial aspects of the notion of national society that were associated with the vision of an expanding welfare state and collective party relations in the labor market were severely challenged in the Nordic countries and elsewhere. The transformations, called globalization, meant increasing social asymmetries concerning the role of spatial ties. The opportunities enjoyed by different actors to choose between alternative forms of relating themselves to their environment - between the three options of what Albert O. Hirschman (1970) called exit, voice and loyalty - were increasingly differentiated. The exit option was available to transnational companies and investors in a new way, and, as a structural mode of exerting influence in national contexts, it tended to make obsolete the previous national forms of using voice and loosened the previous loyalties to the national rules of the game. Solidarity through shared national links became more problematic, and any "concrete utopia" (Bloch 1959) based on an idea of parity between labor and capital within a national society was dissolved.

The project for extending symmetrical party relations lost its political momentum. The premises for the "Nordic" image of symmetry between labor market parties were weakened by a variety of developments: the multi- and transnational character of companies in the global economy, including their dependencies on calculations in global finance markets; the constant restructuring of production processes in accordance with network ideas, including varying forms of outsourcing and sub-contracting; the corresponding transformations in the public sector in the spirit of New Public Management, including the blurring of boundaries between public and private, obligatory and voluntary, and official and unofficial; the increase in so-called "atypical" employment relationships; and the growing fluidity of the boundary between wage work and entrepreneurship. For their part, the management lessons and practices aiming to promote both flexibility and commitment in work organizations blurred the difference between wage work and entrepreneurship. This implied, among other things, that the idea of the 
worker as the weaker part of the worker-employer relationship tended to be pushed to the margin through the ethos of entrepreneurship at the same time as, on the other hand, the asymmetry between capital and labor increased due to the dramatic growth of the mobility of financial capital.

The Nordic industrial relations institutions had presumed the existence of collective parties on various hierarchical levels, most notably at the workplace, within each branch, and on the central national level. This mode of thought and action may be characterized as concentration through centralization. Since the beginning of the 20th century this was, for the Nordic trade union ideologists, the way of producing working class solidarity and rational action in correspondence with the fundamental processes of capitalism, that is, the concentration and centralization of capital. This tradition did not easily fit into the new tendencies of company structures, characterized by Bennett Harrison (1994, pp. 8-12) as "concentration without centralization". It became more difficult to identify, organize, bring together and centralize the "labor market parties" within a national society.

A crucial part of the Nordic model used to be the widening of the scope of issues in which business companies as well as public-sector organizations had to recognize that their interests as employers are no more than a category of particular interests. Especially in the 1960s and 1970s, trade unions, with their considerable power to set the agenda on working life issues, aimed to draw management issues into the sphere of collective industrial relations. However, in the 1980s the direction altered. In defining questions and solutions concerning work and employment, the perspective of management, and in particular, of human resource management, became predominant. In the Nordic countries, as elsewhere, employers accelerated the integration of pay determination and work organization; wage systems were individualized and, more systematically than before, pay was transformed into an instrument of management (Kjellberg 1992, pp. 134-135). The power of management in defining the issues was indicated, for instance, by the vocabulary of working life. In the new rhetoric of human resource management "direct participation" gave an impression of more democracy than "indirect participation" through trade unions and the representative institutions of industrial relations (Sisson 1996).

Corresponding to the hegemonic primacy of the management perspective over the industrial relations perspective (Looise \& van Riemdijk 2001), separate employer organizations were abolished in many European countries, including all Nordic countries. The representation of firms as employers has been included as just one part in the business interest organizations that represent the interest of the "economy" in relation to many different "stakeholders", competitiveness appearing as the core of this universalized interest.

On the other hand, for transnational companies, national business interest organizations are but one category of "stakeholders". What kinds of motives can tie a transnational company to a national business or employer interest organization? This is at least as fundamental a question as are the problems of trade union membership that used to dominate the research on industrial relations. There are plausible motives, and an obvious one is the logic of buying services, i.e. services of interest representation. The need, availability and quality of such services are among the variables according to which the leaders of transnational corporations assess different potential national environments of business. In turn, the nation-states in their hard market competition as producers and 
sellers of business environments for competitive economic performance may include the good-working systems of collective conflict regulation and consensus making as competitive advantages into the brands of their own. ${ }^{3}$

One can find this kind of argumentation also in the advocating of the "European social model", in which "social partners" and "social dialogue" are among the key concepts. The term itself (Sozialpartnerschaft) emerged in Austria after World War II, and referred to common efforts for national economic and political recovery and to overcoming previous cleavages (Hyman 2001; Rainio-Niemi 2008). Its major features can be found in Social Catholicism, which took shape in the late 19th century. In the postWorld War II decades, especially in Austria and West Germany, the notion of "social partnership" had a potential to combine the traditions of Social Catholicism and Social Democracy. The (Social Democratic) "dualism of labor and capital” (Brüggemann 1994, pp. 254) could be interpreted within the framework of the (Catholic) organicist idea of a community in which every member is committed to fulfilling his own function for the common good. This idea implies a norm which reduces societal relationships to personal relationship - a crucial aspect of the Catholic understanding of the principle of subsidiarity in the "social dimension" of the EU (van Kersbergen \& Verbeek 2004).

The discursive power of the notion of "social partners" stems not only from the anchorage of this concept in long traditions of European social thought, but also from its resonance with current tendencies in social political agenda setting. Reading EU documents on "social partners" - for example, the reports on industrial relations in Europe that the European Commission has published every second year since 2000 (European Commission 2000; 2002; 2006; 2008; 2010) - one can make two observations. Firstly, in the talk about social partners, very little is usually said about the diverging compositions of various social partners. The increased global asymmetries between capital and labor disappear behind the symmetrical figures of social partners and social dialogue. Secondly, there are rarely any hints about confronting interests or compromises between the interests. European social dialogue is described as a force for innovation and change, a key to better governance, or a force for economic and social modernization. In these contexts, industrial relations and labor legislation are typically assessed by the criteria of "quality", reflecting the lessons of total quality management.

In the Nordic countries, trade unions and employer organizations have not been "social partners", but "labor market parties". However, it has not been so easy to recognize that the notion of symmetry in "social partners" is different from the ideal of symmetry that used to be influential in the development of Nordic industrial relations. Nor has it been easy to recognize the changes in agenda setting through the new meanings and imperatives of competitiveness.

\section{New meanings to old institutions}

Trade unions in the 1980s and 1990s were reoriented to defend the institutions of collective industrial relations by proving that they were beneficial for the effective management of competitive business. In the Nordic traditions there were some favorable preconditions for a re-orientation. As a central policy objective competitiveness was, as such, far from any novelty in the Nordic countries; it was an integral part of the widely shared post-World War II ideology of virtuous circles (cf. Kasvio 1995; Pekkarinen, 
Pohjola \& Rowthorn 1992). Labor market compromise in the 1930s and 1940s was connected with a consensus concerning the legitimacy of technical and organizational rationalization. There were also specific national traditions combining the horizon of the seller of labor power and the horizon of the subject of the labor process.

In Denmark the category of 'craft' was important. The strength of craft-based unionism makes the Danish trade union movement historically distinct from the Swedish, Norwegian and Finnish union movements, in which the principle of industrybased unionism early achieved a dominant position. For the Danish trade unions it was possible to exploit this tradition "by giving greater emphasis to professional qualifications and training" (Scheuer 1992, pp. 194). In Norway, combining "socio-technical" workplace-level innovations with the efforts to achieve "industrial democracy" began with the experiments of Einar Thorsrud and Fred E. Emery in the 1960s (Venneslan 1990; Naschold 1994, 34; HF-B/LO/NHO 1997). In Sweden, besides similar experiments beginning in the 1970 s, active labor market policies were a strong tradition, in which the principles of full employment, solidarity-based wage policies and increased productivity were more or less successfully interlinked and, furthermore, questions of the quality of labor power were taken into the agenda of collective labor relations (Erixon 2011). In Finland, industrial relations until the 1980s had indicated more "low-trust" elements than in Denmark, Norway and Sweden and, on the other hand, the issues of technical and organizational rationalization had remained to a greater extent in the power sphere of management. In the "new challenges" of globalization, intertwined with the dramatic experiences of the economic crisis in the early 1990s, Finnish trade unions could see a chance for widening their agenda within the framework of national consensus (cf. Alasoini, Kauppinen \& Ylöstalo 1994, pp. 48-49; Ilmonen \& Kevätsalo 1995).

An important factor, common to all Nordic countries, was the strong presence of trade unions on the workplace level as well as on the level of national policy-making (Kjellberg 1998; HF-B/LO/NHO 1997). This meant, for one thing, that a decentralization of industrial relations could be compatible with an active role for trade unions and shop stewards (Lilja 1997; 1998).

The strong but separate unionization of professional employees should also be noted here. The separate organizing of professional employees was rooted, in part, in a Taylorist concept of work organization and, politically, in the reluctance to be bound to a labor movement. These historical preconditions had lost a lot of their significance. However, the organizations of professional employees also reflected the special problems of female-dominated public sector jobs and labor relations, and they contributed to a change of the paradigmatic concept of work, for example, to the adoption of requirements concerning the role of customers for a successful work organization (cf. Julkunen \& Rantalaiho 1993).

The role of trade unions in new competition strategies was not self-evident to employers. In the early 1990s, especially in Sweden, employer organizations showed an explicit reluctance to link collective labor market parties with the new practices of promoting competence and innovative work organizations (SOU 1992:7, pp. 90-91). Through conflicts concerning the actors and contents of competition strategies, the role of competitiveness as the center of the agenda was actually strengthened. Trade union critiques of narrowly economic arguments contributed to the power and legitimacy of the discourse of competitiveness, as the unions developed wider arguments for competitiveness, seeking to prove, for example, that security in working life is a 
necessary precondition for a competitiveness based on the commitment, competence and innovation.

It was easy for the trade unions to accept, at least in their programs, a value-added competition strategy, which is based on innovation, training and participation, as an alternative to the cost-based strategies of social dumping and low-wage competition (e.g. Nordiska Metalls Policy 1993; Locke, Kochan \& Piore 1995). For researchers engaged in the large national working life development programs in the 1990s, it was not difficult to find theoretical and empirical arguments for the positive, active role of trade unions in such good strategies on national, local, company and work-place levels (Gustavsen et al 1995; HF-B/LO/NHO 1997; Alasoini, Kyllönen \& Kasvio 1997; Naschold 1994; Locke, Kochan \& Piore 1995). There seemed to exist, after all, chances to overcome the position of reactive defense against the neo-liberal demands for deregulation. Collective interest representation and even high social norms could be proved to be, not just "rigidities", but competitive advantages, factors promoting the commitment of workers and the innovativeness of firms and their managements. The neo-Schumpeterian emphasis on innovation and the institutional preconditions of innovation were easily adopted in this context (Johnson \& Lundvall 1991). Such tones emerged, in particular, in discussions on education and training. Much of the ideological power of knowledge, education and innovation in the Nordic countries stemmed from the promise that competitiveness and its preconditions in the global economy can - or even must - be seen from a wider perspective than from that of neo-liberal deregulation.

Indeed, the change took place within a remarkable institutional continuity, through an "institutional conversion" (Thelen 2003). The old institutions of the welfare state and industrial relations were now modified to serve the new functions of the competitive community.

In the shaping of the EU social policies, it has been easy for those coming from the Nordic countries to develop and support the principle of "social protection as a productive factor". This slogan was introduced in the EU debates in the late 1990s (Beck et al 2001) and confirmed in connection with the so-called Lisbon Strategy of the EU, 2000-2010, aimed at making Europe by 2010 "the most competitive and dynamic knowledge-based economy in the world capable of sustainable economic growth with more and better jobs and greater social cohesion". The Social Policy Agenda 2000-2005, implementing the Lisbon Strategy (COM (2000)379), advocated a virtuous circle between social policy, economic policy and employment policy and was aimed "to reinforce social policy as a productive factor". The argument includes an economization of social policy in two different senses: as an argument for the recognition of the economic importance of social policy (Magnusson, Jørgensen \& Dølvik 2008) and also as an argument for reforming social policy in a way that could meet the demand of being a productive factor in global competition. Be it implicitly or explicitly, the argument means that the role and meaning of equality is redefined, something that some social policy researchers have also argued for since the 1990s: "the maximization of human capital must take priority to egalitarianism 'here and now" (Esping-Andersen 1996, p. 264). As unsuccessful as the Lisbon strategy was - the strategy period ended with economic crisis - the failures did not diminish the role of competitiveness in the framing of social policies and industrial relations.

It makes a difference whether or not individuals' opportunities to make themselves competitive are shaped by more or less egalitarian systems of education and training, 
and it also makes a difference whether or not the encouragement of knowledge-based competition in working life is connected with collective institutions of social regulation. Nevertheless, a tension appears in Nordic discussions between what are presented as institutional preconditions of competitiveness and how the contents of competitiveness are conceived. At the same time as egalitarian institutions and participatory practices can be defended as preconditions for knowledge-based competitiveness, true membership in a competitive community is a matter of individual competitiveness. This consists of communicative and innovative skills and talents and the reflexive capabilities of monitoring oneself from the point of view of competitiveness. In the orientation towards these objectives, the principles of social equality and collective interests hardly play any role.

\section{Conclusion}

From the different histories of Nordic countries, one can recognize a Nordic pattern of constructing a modern nation-state society, in which institutions were based on waged and salaried work and supported its expansion and normalcy, including the paid work of women outside the home. The far from self-evident or tensionless combination of wage work and social citizenship became the norms for the Nordic notions of society.

The Nordic countries are still at the top of international statistics of trade union membership, and no drastic decline has occurred. The majority of waged and salaried workers are union members, and in this sense the post-1970s picture is different from the general trends in the developed countries. With the rise of neo-liberalism in the 1980s, arguments for radical social-political deregulation also emerged in the Nordic countries, but they were later pushed into the margin. Nevertheless, the ways of discussing and contextualizing "the Nordic model" have changed, and discursive changes have been associated with institutional ones.

In Nordic debates on the future of the welfare state and collective agreements, striking paradoxes appear. Practitioners and researchers of social policy tend to make pessimistic accounts on the present and the future of the welfare state. They have paid attention to the erosion of the so-called universalism in connection with the projects of a knowledge-based competitive society or with the ideas of "workfare" in activation and immigration policies (Kildal \& Kuhnle 2005; Kuivalainen \& Niemelä 2010; Blomberg \& Kildal 2010). At the same time, representatives of business life and many economists have expressed optimistic views on the crucial role of the Nordic model of societal risk sharing for economic performance and competitiveness (Andersen et al. 2007). A slightly different paradoxical turnaround of positions can be found if we look at the arguments for the defense of the welfare state and the arguments for the significance of economic competitiveness. Those defending the welfare state and the system of collective agreements against the pressures of globalized capitalism are arguing that the welfare state actually generates competitive advantages, whereas those concerned about economic competitiveness or government budget discipline motivate these concerns by the necessity to create or rescue resources for the welfare state.

The concept of "model" gained popularity along with discussions on globalization. It refers to encounters between globalized capital and national institutions. In the current usage of "the Nordic model", an interesting ambiguity appears. It may refer to a 
structure that has become threatened through globalization, or to a way of responding to the challenge. The latter meaning is manifested, for example, in the - currently somewhat receded - praising of "the Danish model" of "flexicurity" (Madsen 2004), or "the Finnish model" as a paragon of consensual competitiveness in a new knowledge-based society (Castells \& Himanen 2002), or "the Nordic model" in general, assessed as being capable of embracing globalization by means of risk sharing (Andersen et al 2007). The ambiguity of the concept of model indicates the changing role of the nation state, which can be characterized by the concepts of "welfare state" and "competition state" (Cerny 1990; Streeck 1998; Palan \& Abbot 1999). It may not be reasonable to talk about a shift from the welfare state to a competition state but, rather, to conclude that an ambiguity of the welfare state and the competition state is characteristic of what is currently called "the Nordic model".

The distinction between compromise and consensus, elaborated by Frank Ankersmit (2002, pp. 193-213), is useful for interpreting this change. Compromise is based on the mutual recognition of the particular instead of the universal nature of the interests in question, and the political process does not aim to remove this state of affairs. Consensus, in turn, presupposes a commitment to a common interest defined beforehand, and in the political process only those aspects of the particular interests of the participants which bear elements of the given common interest are recognized.

In nation-state societies, the decisions that are not just made by the coercive power of the strongest forces include elements of both consensus and compromise. The relationship between these two principles, however, varies and changes. The making of the Nordic welfares states and industrial relations systems included the strengthening and institutionalization of compromises between divergent particular interests, and this was legitimized by the confidence in the virtuous circle of social equality, economic growth and widening democracy. The logics of the competition state, following the imperatives of making the national society competitive in the globalized competition between different business environments, points out the principle of consensus, associated with the nationalism inherent in the globalized competition. In Nordic political debates and practices, a vast range of highly valuated work-related policy objectives are proved to be compatible with national competitiveness and included in the competitiveness-oriented consensus. However, one may ask where the limits of such a national consensus are. Failing to recognize those interests and needs that cannot be associated with the project of competitive community implies risks concerning the democratic legitimacy of the "model”.

\section{References}

Alasoini, T., Kauppinen, T. \& Ylöstalo, P. (1994) 'Workplace in Finland - New Forms of Bargaining and Participation', in T. Kauppinen and V. Köykkä (eds.) Workplace Europe New Forms of Bargaining and Participation. IIRA 4th European Regional Congress, Helsinki 24-26 August 1994. Plenary 2: Helsinki: The Finnish Labour Relations Association.

Alasoini, T., Kyllönen, M. \& Kasvio, A. (eds.) (1997) Workplace innovations: a way of promoting competitiveness, welfare and employment. National workplace development programme, Report 3, Yearbook 1997. Helsinki: Ministry of Labour. 
Andersen, T. M., Holmström, B., Honkapohja, S., Korkman, S., Söderström, H. T. \& Vartiainen, J. (2007) The Nordic Model - Embracing Globalization and Sharing Risks. Helsinki: The Research Institute of the Finnish Economy ETLA.

Andersson, J. (2006) Between Growth and Security. Swedish Social Democracy from a Strong Society to a Third Way. Manchester: Manchester University Press.

Ankersmit, F. R. (2002) Political Representation. Stanford: Stanford University Press.

Beck, W., van der Maesen, L. \& Walker, A. (2001) 'Processes Challenging the Concept of Social Quality', in W. Beck (ed.), Social Quality: A Vision for Europe. The Hague: Kluwer Academic Publishers, pp. 287-302.

Bergholm, T. (2012) Kohti tasa-arvoa. Tulopolitiikan aika I. Suomen Ammattilittojen Keskusjärjestö 1969-1977 [Towards equality. The era of incomes policy I. The Central Organization of Finnish Trade Unions SAK 1969-1977]. Helsinki: Otava.

Bloch, E. (1959) Das Prinzip Hoffnung. Frankfurt am Main: Suhrkamp.

Blomberg, H. \& Kildal, N. eds. (2010) Workfare and welfare state legitimacy. NordWel Studies in Historical Welfare State Research 1, Helsinki: NordWel.

Borchorst, A. \& Siim, B. (2008) 'Woman-friendly policies and state feminism: Theorising Scandinavian gender equality'. Feminist Theory, vol. 9, no. 2, pp. 207-224.

Brüggemann, E. (1994) Die menschliche Person als Subjekt der Arbeit. Das, Prinzip des Vorrangs der Arbeit vor dem Kapital' und seine Umsetzung in der heutigen Gesellschaft. Abhandlungen zur Sozialethik. Herausgegeben von Anton Rauscher und Lothar Roos. Band 33. Padenborn/München/Wien/Zürich: Ferdinand Schöningh.

Bruun, N. (1979) Kollektivavtal och rättsideologi. En rättsvetenskaplig studie av de rättsvetenskapliga premisserna för inlemmandet av kollektivavtalet och kollektiva kampåtgärder i finsk rättsordning efter år 1924 [Collective agreement and the ideology of law. A juridical study on the adjustment of collective agreement and industrial action into the Finnish order of law after 1924]. Helsinki: Juridica.

Bruun, N. (1990) 'Den nordiska modellen för facklig verksamhet' [The Nordic model of trade unionism], in N. Bruun, B. Flodgren, M. Halvorsen, H. Hydén \& R. Nielsen: Den nordiska modellen. Fackföreningarna och arbetsrätten $i$ Norden - nu och framtiden [The Nordic model. Trade unions and labour law in the Nordic countries - now and in the future]. Lund: Liber.

Castells, M. \& Himanen, P. (2002) The information society and the welfare state. The Finnish model. Oxford: Oxford University Press.

Cerny, P. G. (1990) The changing architecture of politics. Structure, agency, and the future of the state, London: Sage Publications.

Claussen, T. (2000) Bedriftsutvikling, arbeidsmiliø og filosofi [Enterprise development, working environment and philosophy]. Oslo: Unipub forlag.

COM (2000)379, Communication from the Commission to the Council, the European Parliament, the Economic and Social Committee and the Committee of the Regions. Social policy agenda. Brussels: The Commission of European Communities.

Due, J., Madsen, J. S. \& Strøby Jensen, C. (1994) Den danske model. En historisk sociologisk analys av det kollektive aftalesystem [The Danish model. A historical sociological analysis of the system of collective agreements]. København: Jurist- og Økonomforbundets Forlag,

Edling, N. (2006) 'Limited Universalism: Unemployment insurance in Northern Europe 1900-2000', in N. F. Christiansen, K. Petersen, N. Edling \& P. Haave (eds.) The Nordic Model of Welfare - a Historical Reappraisal. Copenhagen: Museum Tusculanum Press, pp. 99-143.

Elvander, N. (2002) 'The Labour Market Regimes in the Nordic Countries: A Comparative Analysis', Scandinavian Political Studies, vol. 25, no. 2, pp. 117-137. 
Erixon, L. (2011) 'A social innovation or a product of its time? The Rehn-Meidner model's relation to contemporary economics and the Stockholm school', European Journal of the History of Economic Thought, vol. 18, no. 1, pp. 85-123.

Esping-Andersen, G. (1985) Politics against Markets. The Social Democratic Road to Power. Princeton: Princeton University Press.

Esping-Andersen, G. (1990) The Three Worlds of Welfare Capitalism. Cambridge: Polity Press.

Esping-Andersen, G. (1996) 'Positive-Sum Solutions in a World of Trade-Offs?', in Gøsta Esping-Andersen (ed), Welfare States in Transition. National Adaptations in Global Economies, London: Sage Publications, pp. 256-67.

European Commission (2000, 2002, 2004, 2006, 2008) Industrial Relations in Europe 2000, 2002, 2003, 2004, 2006, 2008. Brussels: European Commission.

Flodgren, B. (1990) 'Företagsdemokrati - medbestämmande' [Industrial democracy - codetermination], in N. Bruun, B. Flodgren, M. Halvorsen, H. Hydén \& R. Nielsen: Den nordiska modellen. Fackföreningarna och arbetsrätten $i$ Norden - nu och framtiden [The Nordic model. Trade unions and labour law in the Nordic countries - now and in the future]. Lund: Liber.

Gustavsen, B., Hofmaier, B., Ekman, M. \& Wikman, A. (1995) Utvecklingslinjer i arbetslivet och Arbetslivsfondens roll [Lines of development in working life and the role of the Working Life Foundation]. Stockholm: SNS Förlag.

Harrison, B. (1994) Lean and Mean. The Changing Landscape of Corporate Power in the Age of Flexibility. New York: BasicBooks.

HF-B/LO/NHO in co-operation with I. Munkeby and M. Malmo (1997) 'Norway's social partners' joint programme for enterprise development', in A. Tolentino (ed.) Workers: Stakeholders in productivity in changing global economic environment. EMD/18/E. Enterprise and Management Development. Geneva: International Labour Office.

Hirschman, A. O. (1970) Exit, Voice, and Loyalty. Responses to Decline in Firms, Organizations, and States. Cambridge, MA and London: Harvard University Press.

Hyman, R. (2001) Understanding European trade unionism: between market, class and society. London: Sage Publications.

Ilmonen, K. \& Kevätsalo, K. (1995) Ay-liikkeen vaikeat valinnat. Sosiologinen näkökulma ammatilliseen järjestäytymiseen Suomessa [The difficult choices of trade union movement. A sociological perspective to unionization in Finland]. Helsinki: Palkansaajien tutkimuslaitos.

Jessop, B. (1995) 'The Regulation Approach, Governance, and Post-Fordism: Alternative Perspectives on Economic and Political Change?', Economy and Society, vol. 24, no. 3, pp. 307-333.

Johnson, B. \& Lundvall, B.-Å. (1991) 'Flexibility and Institutional Learning', in H. Kastendiek, K. Nielsen \& O. K. Pedersen (eds.) The Politics of Flexibility. Restructuring State and Industry in Britain, Germany and Scandinavia. Aldershot: Edward Elgar.

Julkunen, R. \& Rantalaiho, L. (1993) 'Women on strike - non-existent or silenced?', in P. Kettunen (ed.) Strike and Social Change. Turku: Turku Provincial Museum.

Kasvio, A. (1995) Reinventing the Nordic model - Can the Nordic countries succeed in 21st century global competition. Tampere: Tampereen yliopisto.

Katzenstein, P. J. (1985) Small States in World Markets: Industrial Policy in Europe, Ithaca and New York: Cornell University Press.

Kauppinen, T. (1994) The Transformation of Labour Relations in Finland. Helsinki: Finnish Labour Relations Association.

Kern, H. \& Schumann, M. (1984) 'Work and social character: old and new contours'. Economic and Industrial Democracy, vol. 5, no. 1. 
van Kersbergen, K. \& Verbeek, B. (2004) 'Subsidiarity as a Principle of Governance in the European Union', Comparative European Politics, 2, pp. 142-162.

Keskitalo, E. (2008) Balancing Social Citizenship and New Paternalism - Finnish activation policy and street-level practice in a comparative perspective, Helsinki: National Research and Development Centre for Welfare and Health Stakes.

Kettunen, P. (1998) 'Globalisation and the Criteria of 'Us' - A Historical Perspective on the Discussion of the Nordic Model and New Challenges', in D. Fleming, P. Kettunen, H. Søborg \& Christer Thörnqvist (eds.): Global Redefining of Working Life - A New Nordic Agenda for Competence and Participation? Nord 1998: 12. Nordic Council of Ministers, Copenhagen 1998, pp. 33-80.

Kettunen, P. (2006) 'Power of International Comparison - A Perspective on the Making and Challenging of the Nordic Welfare State', in N. F. Christiansen, K. Petersen, N. Edling @ P. Haave (eds.), The Nordic Model of Welfare - a Historical Reappraisal, Copenhagen: Museum Tusculanum Press, pp. 31-65.

Kettunen, P. (2009) 'The Nordic Model and the International Labour Organization', in N. Götz and H. Haggrén (eds.) Regional Cooperation and International Organizations. The Nordic Model in Transnational Alignment, London: Routledge, pp. 67-87.

Kettunen, P. (2010) 'The sellers of labour power as social citizens - A Utopian wage work society in the Nordic visions of welfare', in H. Blomberg \& N. Kildal (eds.) Workfare and welfare state legitimacy. NordWel Studies in Historical Welfare State Research 1, NordWel, Helsinki 2010, pp. 16-45.

Kettunen, P. (2011) 'The transnational construction of national challenges: the ambiguous Nordic model of welfare and competitiveness', in P. Kettunen \& K. Petersen (eds.) Beyond Welfare State Models - Transnational Historical perspectives on Social Policy. Edward Elgar Publishing, Cheltenham, UK \& Northampton, MA, USA, 2011, pp. 16-40.

Kettunen, P. \& Turunen, I. (1994) 'The Middle Class, Knowledge and the Idea of the Third Factor', Scandinavian Journal of History, vol. 19, no. 1, pp. 63-86.

Kettunen, P. \& Petersen, K. (2011) 'Introduction: rethinking welfare state models', in P. Kettunen \& K. Petersen (eds.) Beyond Welfare State Models - Transnational Historical perspectives on Social Policy. Edward Elgar Publishing, Cheltenham, UK \& Northampton, MA, USA, 2011, pp. 1-15.

Kildal, N. \& Kuhnle, S. (2005) 'The Nordic welfare model and the idea of universalism', in N. Kildal \& S. Kuhnle (eds.) Normative Foundations of the Welfare State - The Nordic Experience. London/New York: Routledge.

Kjellberg, A. (1983) Facklig organisering i tolv länder. Forskningsprojektet "Sverige under socialdemokratin 1932-76. "[Unionization in twelve countries. The research project" Sweden under Social Democracy, 1932-76]. Lund: Arkiv.

Kjellberg, A. (1992) 'Sweden: Can the Model Survive?', in A. Ferner \& R. Hyman (eds.) Industrial Relations in the New Europe. Oxford: Blackwell, pp. 88-142.

Kjellberg, A. (1998) 'Sweden: Restoring the Model', in A. Ferner \& R. Hyman (eds.) Changing Industrial Relations in Europe. Oxford: Blackwell Publishers, pp. 74-117.

Knudsen, H. (1995) Employee Participation in Europe. London: Sage Publications.

Kuivalainen, S. \& Niemelä, M. (2010) 'From universalism to selectivism: the ideational turn of the anti-poverty policies in Finland', Journal of European Social Policy vol. 20, no. 3.

Kulawik, T. (2002) 'The Nordic Model of the Welfare State and the Trouble with a Critical Perspective', Nyhetsbrev för nordisk välfärdshistoria, no. 21, pp. 2-8.

Lilja, K. (1992) 'Finland: No longer the Nordic Exception', in A. Ferner \& R. Hyman (eds.) Industrial Relations in the New Europe. Oxford: Blackwell, pp. 198-217.

Lilja, K. (1997) 'Bargaining for the Future. The Changing Habitus of the Shop Steward System in the Pulp and Paper Mills of Finland', in R. D. Whitley \& P. H. Kristensen (eds.) 
Governance at Work. The Social Regulation of Economic Relations. Oxford: Oxford University Press, pp. 123-136.

Lilja, K. (1998) 'Finland: Continuity and Modest Moves Towards Company-level Corporatism', in A. Ferner \& R. Hyman (eds.) Changing Industrial Relations in Europe. Oxford: Blackwell Publishers, pp. 171-189.

Lloyd, C. (2011) 'The history and future of social democratic welfare capitalism: from modernization to the specters of ultramodernity', in P. Kettunen \& K. Petersen (eds.) Beyond Welfare State Models - Transnational Historical perspectives on Social Policy. Edward Elgar Publishing, Cheltenham, UK \& Northampton, MA, USA, 2011, pp. 199-217.

Locke, R. M., Kochan, T. \& Piore, M. J. (1995) 'Reconceptualising comparative industrial relations: Lessons from international research', International Labour Review, vol. 134, no. 2.

Lohmann, G. (1986) 'Marx's Capital and the question of normative standards', Praxis International, vol. 6, no. 3, pp. 353-372.

Looise, J. C. \& van Riemsdijk, M. J. (2001) 'Globalisation and human resource management: the end of industrial relations?', in Gyorgy Széll (ed.) European Labour Relations. vol. 1. Aldershot: Ashgate Publishers, pp. 280-296.

Madsen, P. K. (2004) 'The Danish model of "flexicurity": experiences and lessons', Transfer European Review of Labour and Research, Vol 10, no. 2, pp. 187-207.

Magnusson, L., Jørgensen, H. \& Dølvik, J. E. (2008) The Nordic Approach to Growth and Welfare: European Lessons to be Learned? Brussels: European Trade Union Institute.

Marshall, T. H. (1950) Citizenship and Social Class, and Other Essays. Cambridge: Cambridge University Press.

Naschhold, F. (1994) The Politics and Economics of Workplace Development. A Review of National Programmes. Työpoliittinen tutkimus 64. Helsinki: Ministry of Labour.

Nelson, G. R. (ed.) (1953) Freedom and Welfare: Social Patterns in the Northern Countries of Europe, Copenhagen: The Ministries of Social Affairs of Denmark, Finland, Iceland, Norway, Sweden.

Nordiska Metall (1993) Nordiska Metalls Policy. Policydokument angående lagar, industripolitik och kompetensutveckling samt samarbetsavtal och gemensamma mål för de nordiska fackförbunden inom metallindustrin [The policy of Nordiska Metall. A policy document on legislation, industry policies and competence development, and an agreement on cooperation and joint objectives for the Nordic trade unions in metall industries]. Nordiska Metall.

Offe, C. (1984) Contradictions of the welfare state. Edited by John Keane. London: Hutchinson.

Offe, C. \& Wiesenthal, H. (1980) 'Two Logics of Collective Action: Theoretical Notes on Social Class and Organizational Form', Political Power and Social Theory, vol 1, pp. 67-115.

Palan, R., Abbot, J. \& Deans, P. (1999) State Strategies in the Global Political Economy, London and New York: Pinter.

Pekkarinen, J., Pohjola, M. \& Rothstein, B. (1992) 'Social corporatism and economic performance. Introduction and conclusion', in J. Pekkarinen, M. Pohjola \& B. Rowthorn (eds.) Social Corporatism - A Superior Economic System? Oxford: Clarendon Press.

Petersen, K. (2006) 'Constructing Nordic Welfare? Nordic Social Political Cooperation 1919-1955', in N. F. Christiansen, K. Petersen, N. Edling \& P. Haave (eds.) The Nordic Model of Welfare - a Historical Reappraisal. Copenhagen: Museum Tusculanum Press.

Petersen, K. \& Amark, K. (2006) 'Old Age Pensions in the Nordic Countries, 1880-2000', in N. F. Christiansen, K. Petersen, N. Edling \& P. Haave (eds.) The Nordic Model of Welfare - a Historical Reappraisal. Copenhagen: Museum Tusculanum Press.

Polanyi, K. (2001 [1944]) The Great Transformation. The Political and Economic Origins of Our Time. Forword by Joseph E. Stiglitz. Boston: Beacon Press.

Rainio-Niemi, J. (2008) Small State Cultures of Consensus. State Traditions and ConsensusSeeking in the Neo-Corporatist and Neutrality Policies in Post-1945 Austria and Finland, Doctoral Dissertation. Helsinki: University of Helsinki, Faculty of Social Sciences. 
Salvesen, K. (1956) 'Co-operation in Social Affairs between the Northern Countries of Europe', International Labor Review, vol. LXXIII, pp. 334-57.

Scheuer, S. (1992) 'Denmark: Return to Decentralization', in A. Ferner \& R. Hyman (eds.) Industrial Relations in the New Europe. Oxford: Blackwell.

Senghaas, D. (1985) The European Experience. A Historical Critique of Development Theory. Leamington Spa/Dover, New Hampshire: Berg Publishers.

Sisson, K. (1996) Closing the Gap. Ideas and Practice. Direct Participation in Organizational Change. Dublin: EPOC.

SOU 1935: 65. Betänkande om folkförsörjning och arbetsfred, Del I. Förslag [A report on the maintenance of people and industrial peace]. Statens Offentliga Utredningar [Swedish Government Official Reports] 1935: 65, Stockholm.

SOU 1992: 7. Kompetensutveckling - en nationell strategi. Slutbetänkande frän kompetensutredningen [The competence development - a national strategy. The final report of the committee on competence development]. Statens Offentliga Utredningar [Swedish Government Official Reports] 1992: 7, Stockholm.

van Stel, A. (2008) 'COMPENDIA Data Base: COMparative ENtrepreneurhip Data for International Analysis', in Emilio Congregado (ed.) Measuring Entrepreneurship: Building a Statistical System. International Studies in Entrepreneurship. New York: Springer.

Streeck, W. (1998) 'Industrielle Beziehungen in einer internationalisierten Wirtschaft', in U. Beck (ed.), Politik der Globalisierung, Frankfurt am Main: Suhrkamp, pp. 169-202.

Stokke, T. A. (2002) 'Conflict regulation in the Nordic countries', Transfer - European Review of Labour and Research, vol. 8, nr. 4.

Thelen, K. (2003) 'How Institutions Evolve - Insights from Comparative Historical Analysis', in J. Mahoney \& D. Rueschemeyer (eds.) Comparative Historical Analysis in Social Sciences. Cambridge: Cambridge University Press, pp. 208-240.

Trägårdh, L. (1997) 'Statist Individualism: On the Culturality of the Nordic Welfare State', in Ø. Sørensen \& B. Stråth (eds.) The Cultural Construction of Norden, Oslo: ScandinavianUniversity Press, pp. 253-285.

Venneslan, K. (1990) 'Industrielt demokrati in Norden. Redogørelse for det norske delprosjektet' [Industrial democracy in Norway - a report of the Norwegian sub-project], in D. Fleming (ed.) Industriell demokrati $i$ Norden [Industrial democracy in the Nordic countries]. Lund: Arkiv, pp. 9-22.

Winner, L. (1995) 'Citizen Virtues in a Technological Order'. In A. Feenberg \& A. Hannay (eds.) Technology and the Politics of Knowledge. Bloomington, Indianapolis: Indiana University Press, pp. 65-84.

\section{End notes}

${ }^{1}$ Declaration concerning the aims and purposes of the International Labour Organisation (Declaration of Philadelphia). www.ilo.org/ilolex/english/constq.htm.

2 This mode of thought was formulated, e.g. in a Swedish governmental committee report that paved the way for the Saltsjöbaden Agreement of 1938, by proposing that the labor market parties should "depoliticize" their mutual relationships in order to be able to realize, through their compromises, the interest of "society". SOU 1935:65, p. 129.

${ }^{3}$ In Finland, a commission for developing the country brand of Finland was nominated in 2008 by Foreign Minister Alexander Stubb and gave its report in 2010. It was chaired by Jorma Ollila, the then president of the boards of Nokia and Shell, who has on several occasions - also when active as the CEO of Nokia in 1992-2006 - expressed his views on the economic benefits of the "Nordic model". 